\title{
DIAGNOSIS DAN TATALAKSANA INFEKSI HIV PADA NEONATUS
}

\author{
Darmadi, Riska Habriel Ruslie \\ Dokter RSUD Z.A. Pagar Alam, Way Kanan, Lampung \\ email :t1c11@yahoo.com
}

\begin{abstract}
Abstrak
Pada tahun 2009, 1,4 juta wanita hamil di negara berpendapatan menengah dan rendah terdiagnosis HIV. Identifikasi awal infeksi HIV, pemberian terapi antiretrovirus, dan supresi virus ke level yang tidak terdeteksi sudah terbukti memperpanjang usia hidup dan mencegah morbiditas pada pasien dewasa. Secara teori prinsip supresi virus pada bayi tidak berbeda dengan dewasa. Namun data mengenai manajemen infeksi HIV pada anak khususnya neonatus masih terbatas. Sehingga disusun literatur yang membahas diagnosis dan manajemen infeksi HIV pada neonatus.
\end{abstract}

Kata kunci. HIV, HIV di neonatus, transmisi vertikal, antiretrovirus

Abstract

In 2009, 1.4 million pregnant women in low and middle-income countries diagnosed HIV. The early identification of HIV infection, the administration of antiretroviral therapy, and the suppression of viral loads to undetectable levels all have been shown to prolong life and prevent morbidity in adults. In theory the principle of viral load suppression would apply to infants as well as adults. However data about the management of HIV infection in children especially in newborns is limited. So in this review examines the diagnosis and management of HIV infection im newborns.

Key word: HIV, neonatal HIV, vertical transmission, antiretroviral 


\section{PENDAHULUAN}

Human Immunodeficiency Virus (HIV) adalah RNA retrovirus yang menyebabkan Acquired Immunodeficiency Syndrome (AIDS), di mana terjadi kegagalan sistem imun progresif. Penyebab terbanyak adalah HIV-1. Virus ini ditransmisikan melalui hubungan seksual, darah, produk yang terkontaminasi darah, dan transmisi dari ibu ke bayi baik intrapartum, perinatal, atau ASI. ${ }^{(1)}$ Pada intrapartum, fetus dapat terinfeksi secara hematogen karena sirkulasi uteroplasenta melalui membran amnion, terutama apabila membran mengalami inflamasi atau infeksi. Pada periode perinatal, infeksi vertikal lebih banyak terjadi. Semakin lama dan besar jumlah kontak neonatus dengan darah ibu dan sekresi servikovaginal, risiko transmisi vertikal juga bertambah besar. Prematuritas dan berat badan lahir rendah pada neonatus juga meningkatkan risiko infeksi dalam persalinan karena menipisnya barier pertahanan dari kulit dan sistem imun. Pasca persalinan, transmisi vertikal dapat terjadi karena bayi mendapat ASI dari ibu yang menderita HIV. ${ }^{(1)}$

Pada tahun 2009, 1,4 juta wanita hamil di negara berpendapatan menengah dan rendah terdiagnosis HIV ${ }^{(2)}$ Lebih dari $90 \%$ infeksi HIV pada bayi dan anak ditransmisikan oleh ibu selama kehamilan, kelahiran, atau ASI. Tanpa intervensi apapun, $15-45 \%$ bayi yang lahir dari ibu dengan HIV menjadi terinfeksi (5-10\% selama kehamilan, 10-20\% selama kelahiran, dan 5-20\% lewat ASI). Sekitar $50 \%$ bayi yang terinfeksi HIV dari ibunya meninggal sebelum usia 2 tahun. Transmisi infeksi HIV dari ibu ke bayi dapat diturunkan jika obat antiretroviral diberikan pada ibu selama kehamilan dan kelahiran dan bayi setelah kelahiran. $^{(2)}$

Walaupun infeksi nasional HIV di Asia lebih rendah dibandingkan dengan benua lain (misalnya Afrika), populasi dari banyak negara di Asia sangat besar sehingga bahkan prevalensi yang rendah mencerminkan populasi penderita HIV yang sangat banyak. Kecenderungan peningkatan jumlah penderita HIV/AIDS dari tahun ke tahun tersebut membutuhkan penanganan serius. ${ }^{(3)}$

\section{ISI}

Terdapat 3 pola penurunan CD4+ pada bayi. Sekitar $15-25 \%$ neonatus yang terinfeksi HIV di negara miskin dan berkembang mengalami perkembangan penyakit yang cepat dan gejalanya pada bulan-bulan awal kehidupan dan jika tidak dirawat maka harapan hidup berkisar antara 6-9 bulan. Kebanyakan anak-anak pada kelompok ini memiliki kultur HIV-1 positif atau virus terdeteksi pada plasma dalam 48 jam pertama kehidupan, menunjukkan bahwa neonatus mungkin terinfeksi in utero. Viral load secara cepat meningkat pada usia 2-3 bulan dan menurun secara lambat. Berbeda pada dewasa, viral load pada bayi tetap tinggi pada setidaknya dua tahun pertama kehidupan. $^{(4)}$

Mayoritas neonatus yang terinfeksi secara perinatal $(60-80 \%)$ pada negara maju muncul dengan pola kedua, yaitu progresi lebih lambat dengan kemungkinan hidup 6 tahun. Banyak pasien di kelompok ini memiliki kultur virus yang negatif atau PCR yang negatif pada minggu pertama kehidupan dan mungkin terinfeksi intrapartum. Biasanya, viral load secara cepat meningkat pada usia 2-3 bulan pertama kehidupan dan secara lambat mengalami penurunan sekitar usia 24 bulan. ${ }^{(4)}$

Pola ketiga yaitu $<5 \%$ dari anak yang terinfeksi pada periode perinatal dengan progresi minimal atau tanpa progresivitas dengan angka CD4+ yang normal dan viral load yang sangat 
rendah hingga usia 8 tahun. Mekanisme sistemik dan paru yang umum perlambatan dari progresivitas penyakit ditemukan di Amerika Serikat dan termasuk imunitas humoral yang efektif Eropa, sedangkan malnutrisi berat dan/atau respon CTL, faktor genetik mendominasi di Afrika. Gejala ditemupejamu (profil HLA) dan infeksi virus kan lebih sering pada anak-anak yang lemah. ${ }^{(4)}$

\section{Manifestasi Klinis}

Manifestasi klinis infeksi HIV daripada orang dewasa dengan infeksi HIV, termasuk infeksi bakteri berulang, pembengkakan parotis kronis, pneumobervariasi secara luas di antara bayi, dini untuk penurunan neurologis anak-anak, dan remaja. Pada banyak progresif. ${ }^{(1,5)}$ bayi, pemeriksaan fisik saat lahir adalah normal. Gejala awal mungkin hampir tidak terlihat, seperti limfadenopati dan hepatosplenomegali, atau spesifik seperti keterlambatan pertumbuhan, berdasarkan CD4+ dan hitung limfosit diare kronis atau berulang, pneumonia total.

interstisial, atau sariawan. Temuan

\section{Diagnosis}

Berikut ini ditampilkan tabel kriteria klinis HIV, tabel kriteria imunologis

Tabel 1. Kriteria Klinis WHO ${ }^{(6)}$

\begin{tabular}{|c|c|}
\hline \multicolumn{2}{|c|}{$\begin{array}{c}\text { Klasifikasi WHO berdasarkan penyakit yang secara klinis } \\
\text { berhubungan dengan HIV }\end{array}$} \\
\hline Klinis & Stadium klinis WHO \\
\hline Asimtomatik & 1 \\
\hline Ringan & 2 \\
\hline Sedang & 3 \\
\hline Berat & 4 \\
\hline
\end{tabular}




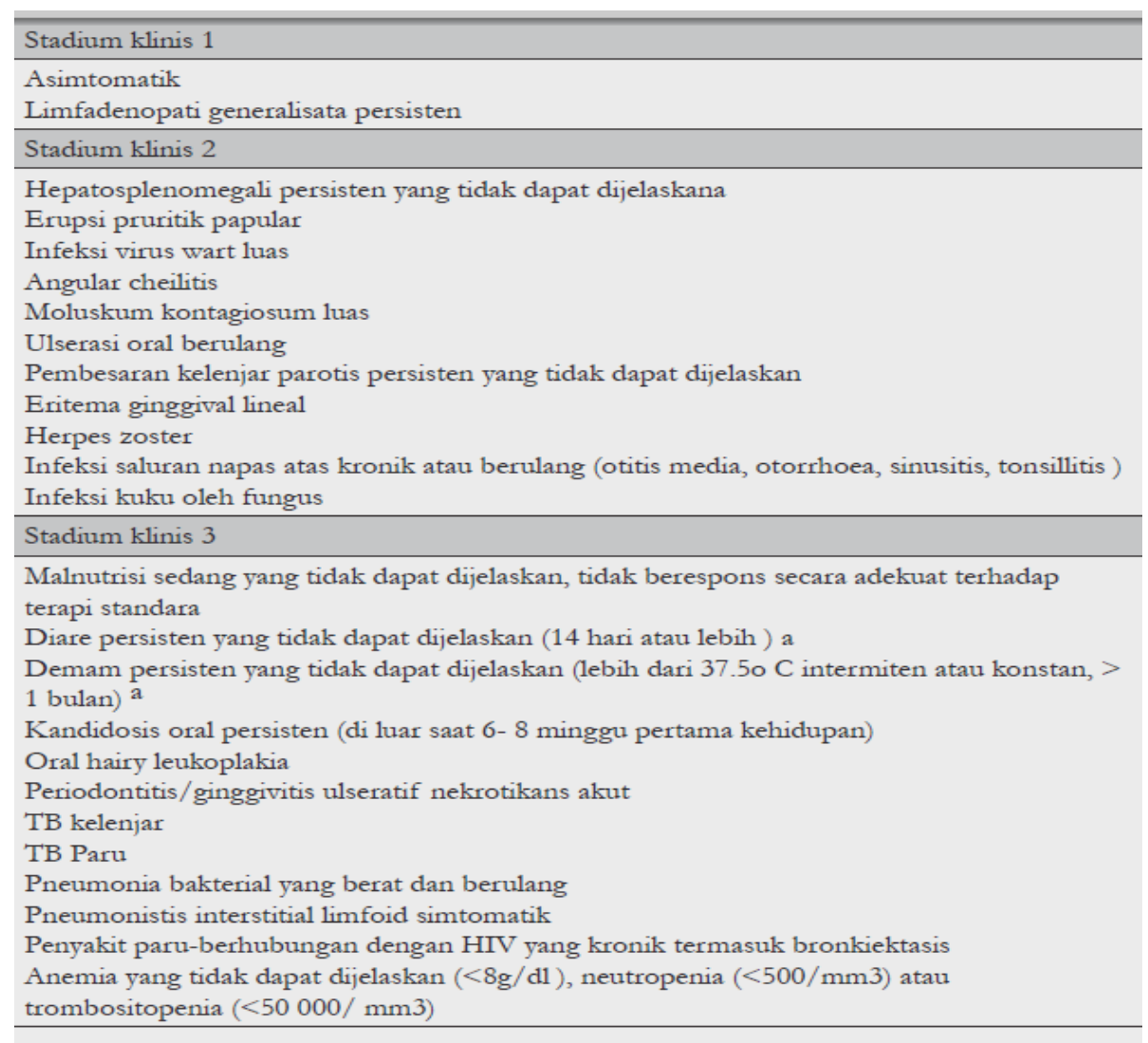

Stadium klinis $4^{\text {b }}$

Malnutrisi, wasting dan stunting berat yang tidak dapat dijelaskan dan tidak berespons terhadap terapi standara

Pneumonia pneumosistis

Infeksi bakterial berat yang berulang (misalnya empiema, piomiositis, infeksi tulang dan sendi, meningitis, kecuali pneumonia)

Infeksi herpes simplex kronik (orolabial atau kutaneus $>1$ bulan atau viseralis di lokasi manapun)

TB ekstrapulmonar

Sarkoma Kaposi

Kandidiasis esofagus (atau trakea, bronkus, atau paru)

Toksoplasmosis susunan saraf pusat (di luar masa neonatus)

Ensefalopati HIV

Infeksi sitomegalovirus (CMV), retinitis atau infeksi CMV pada organ lain, dengan onset umur > 1bulan

Kriptokokosis ekstrapulmonar termasuk meningitis

Mikosis endemik diseminata (histoplasmosis, coccidiomycosis)

Kriptosporidiosis kronik (dengan diarea)

Isosporiasis kronik

Infeksi mikobakteria non-tuberkulosis diseminata

Kardiomiopati atau nefropati yang dihubungkan dengan HIV yang simtomatik

Limfoma sel B non-Hodgkin atau limfoma serebral

Progressive multifocal leukoencephalopathy

Catatan:

a. Tidak dapat dijelaskan ebrarti kondisi tersebut tidak dapat dibuktikan oleh sebab yang lain

b. Beberapa kondisi khas regional seperti Penisiliosis dapat disertakan pada kategori ini 
Tabel 2. Kriteria Imunologis Berdasarkan CD4+ $(\text { WHO })^{(6)}$

\begin{tabular}{|l|c|c|c|c|}
\hline \multicolumn{5}{|c|}{ Klasifikasi WHO tentang imunodefisiensi HIV menggunakan CD4+ } \\
\hline \multirow{2}{*}{ Imunodefisiensi } & \multicolumn{4}{|c|}{ Nilai CD4+ menurut umur } \\
\cline { 2 - 5 } & $<11$ bulan (\%) & $12-35$ bulan (\%) & 36-59 bulan (\%) & $\geq 5$ tahun $\left(\mathbf{s e l} / \mathbf{m m}^{3}\right)$ \\
\hline Tidak ada & $>35$ & $>30$ & $>25$ & $>500$ \\
\hline Ringan & $30-35$ & $25-30$ & $20-25$ & $350-499$ \\
\hline Sedang & $25-30$ & $20-25$ & $15-20$ & $200-349$ \\
\hline Berat & $<25$ & $<20$ & $<15$ & $<200$ atau $<15 \%$ \\
\hline
\end{tabular}

CD4+ adalah parameter terbaik persentase $\mathrm{CD} 4+$. Bila $\geq 5$ tahun, untuk mengukur imunodefisiensi. persentase CD4+ dan nilai CD4+ Digunakan bersamaan dengan penilaian absolut dapat digunakan. Ambang batas klinis. CD4+ dapat menjadi petunjuk kadar CD4+ untuk imunodefisiensi dini progresivitas penyakit karena nilai berat pada anak $\geq 1$ tahun sesuai dengan CD4+ menurun lebih dahulu dibanding- risiko mortalitas dalam 12 bulan (5\%). kan kondisi klinis. Pemantauan CD4+ Pada anak $<1$ tahun atau bahkan $<6$ dapat digunakan untuk memulai pem- bulan, nilai CD4+ tidak dapat berian ARV atau penggantian obat. memprediksi mortalitas, karena risiko Makin muda umur, makin tinggi nilai kematian dapat terjadi bahkan pada CD4+. Untuk anak $<5$ tahun digunakan nilai CD4+ yang tinggi. ${ }^{(6)}$

\section{Tabel 3. Kriteria Imunologis Berdasarkan Hitung Limfosit Total (WHO) ${ }^{(6)}$}

\begin{tabular}{|c|c|c|c|c|}
\hline \multicolumn{5}{|c|}{ Klasifikasi imunodefisiensi WHO menggunakan TLC } \\
\hline \multirow{4}{*}{} & \multicolumn{4}{|c|}{ Nilai TLC berdasarkan umur } \\
\cline { 2 - 5 } & $\begin{array}{c}<11 \text { bulan } \\
(\mathrm{sel} / \mathrm{mm} 3)\end{array}$ & $\begin{array}{c}12-35 \text { bulan } \\
(\mathrm{sel} / \mathrm{mm} 3)\end{array}$ & $\begin{array}{c}36-59 \text { bulan } \\
(\mathrm{sel} / \mathrm{mm} 3)\end{array}$ & $\begin{array}{c}\mathbf{2 5} \text { tahun } \\
(\mathrm{sel} / \mathrm{mm} 3)\end{array}$ \\
\hline TLC & $<4000$ & $<3000$ & $<2500$ & $<2000$ \\
\hline CD4+ & $<1500$ & $<750$ & $<350$ & atau $<200$ \\
\hline
\end{tabular}

Hitung limfosit total (TLC) IgM anti-HIV pada sirkulasi bayi digunakan bila pemeriksaan CD4+ tidak mengindikasi infeksi HIV karena tersedia untuk kriteria memulai ART immunoglobulin ini tidak melewati (imunodefisiensi berat) pada anak plasenta. IgA dan IgM anti-HIV tidak dengan stadium 2. Hitung TLC tidak sensitif dan spesifik, oleh karena itu dapat digunakan untuk pemantauan tidak digunakan dalam klinis. ${ }^{(1)}$

terapi ARV. Perhitungan TLC $=\%$ limfosit $\mathrm{x}$ hitung total leukosit. ${ }^{(6)}$

Antibodi HIV maternal yang

Semua bayi yang lahir dari ibu terinfeksi HIV memiliki antibodi saat lahir oleh karena transfer pasif dari antibodi HIV ibu melewati plasenta selama kehamilan. Banyak bayi yang tidak terinfeksi kehilangan antibodi dari ibu antara usia $6-12$ bulan dan disebut sebagai seroverter. Adanya IgA atau berisiko tinggi mendapat infeksi HIV, 
namun diagnosis definitif menggunakan uji antibodi HIV hanya dapat dilakukan saat usia 18 bulan. $^{(6)}$

Untuk memastikan diagnosis HIV pada anak dengan usia $<18$ bulan, dibutuhkan uji virologi HIV yang dapat memeriksa virus atau komponennya. Anak dengan hasil positif pada uji virologi HIV pada usia berapapun dikatakan terkena infeksi HIV. Anak yang mendapat ASI akan terus berisiko terinfeksi HIV sehingga infeksi HIV baru dapat disingkirkan bila pemeriksaan dilakukan setelah ASI dihentikan > 6 minggu. Hasil uji antibodi HIV pada anak yang pemberian ASInya sudah dihentikan dapat menunjukkan hasil negatif pada $4-26 \%$ anak tergantung usia anak saat diuji, oleh karena itu uji antibodi HIV konfirmasi perlu dilakukan saat usia 18 bulan. $^{(6)}$

Untuk menegakkan diagnosis presumptif pada bayi dan anak $<18$ bulan dengan ada tanda atau gejala HIV yang berat dan bila ada 1 kriteria di antara PCP, meningitis kriptokokus, kandidiasis esofagus, toksoplasmosis, malnutrisi berat yang tidak membaik dengan pengobatan standar atau minimal 2 gejala di antara oral thrush, pneumonia berat, sepsis berat, kematian ibu yang berkaitan dengan HIV atau penyakit HIV yang lanjut pada ibu, CD $4+<20 \%$. $^{(6)}$

\section{Manajemen}

Prevention of Mother to Child Transmission (PMTCT) adalah pencegahan penularan HIV dari seorang wanita HIV positif kepada anaknya selama kehamilan, persalinan, atau menyusui. Istilah ini digunakan karena sumber langsung dari infeksi adalah ibu. Sejalan dengan standar internasional, kebijakan tentang PMTCT menyatakan empat elemen penting dalam rangka mencegah HIV di antara perempuan dan anak-anak. Empat elemen PMTCT ini adalah pencegahan primer HIV, terutama di kalangan wanita usia subur; mencegah kehamilan yang tidak diinginkan pada perempuan pengidap HIV; mencegah penularan HIV dari wanita penderita HIV yang tinggal dengan bayinya; memberikan pengobatan yang tepat, perawatan, dan dukungan kepada perempuan penderita HIV, anak serta keluarganya. ${ }^{(7)}$

\section{Antepartum}

Estimasi transmisi HIV 20\% terjadi sebelum usia 36 minggu, 50\% pada beberapa hari sebelum kelahiran, dan $30 \%$ intrapartum. Transmisi vertikal lebih umum terjadi pada bayi prematur, terutama deSngan ketuban pecah lama. ${ }^{(8)}$

Antenatal care bertujuan untuk memperbaiki kualitas kesehatan ibu dan mencegah mortalitas; identifikasi perempuan dengan HIV positif; meyakinkan perempuan dengan HIV positif untuk mengikuti program PMTCT; mencegah transmisi dari ibu ke anaknya; menyediakan AZT sejak usia kehamilan 14 minggu atau ART seumur hidup sesegera mungkin. ${ }^{(7)}$

Tes HIV harus dilakukan sebagai langkah pertama pada pelayanan antenatal. Jika hasil tes negatif dan wanita yang diperiksa asimtomatik, dianggap sebagai HIV negatif. Wanita dengan HIV negatif perlu disarankan untuk tes ulang pada usia kehamilan 32 minggu untuk mendeteksi serokonversi atau infeksi yang baru terjadi. Jika tes skrining positif dengan ELISA (sensitivitas $>99,5 \%$ ), perlu dikonfirmasi lagi dengan Western blot atau immunofluorescence assay (IFA), dimana keduanya memiliki spesifisitas yang tinggi. ${ }^{(8)}$

\section{Terapi Antiretroviral}

Terapi ini direkomendasikan kepada semua wanita hamil dengan HIV karena menurunkan risiko trans- 
misi perinatal tanpa memperhatikan jumlah CD4+ atau HIV RNA. ${ }^{(9-11)}$ Secara umum, Highly Active Antiretroviral Therapy (HAART) dimulai bila ibu belum mendapat salah satu rejimen. Ketaatan dalam meminum obat sangat penting karena risiko resistensi obat akan menurun. Ibu yang telah meminum HAART saat kehamilan sebaiknya melanjutkan rejimen bila terdapat supresi virus yang adekuat. Efavirenz merupakan pengecualian, di mana harus dihentikan oleh karena efek teratogenik. Sampai sekarang, penambahan zidovudine pada semua rejimen direkomendasikan. ${ }^{(8)}$

Wanita hamil sebaiknya dibagi berdasarkan stadium klinis dan jumlah CD4+. Kriteria pemberian pada wanita hamil: Wanita dengan CD4 lebih dari $350 \mathrm{sel} / \mathrm{mm}^{3}$ dan tergolong dalam stadium 1 dan 2 sebaiknya mendapatkan profilaksis antiretrovirus dengan AZT untuk mengurangi transmisi ke bayinya. Wanita dengan CD4 350 $\mathrm{sel} / \mathrm{mm}^{3}$ atau kurang dari $350 \mathrm{sel} / \mathrm{mm}^{3}$ dan tergolong stadium 3 dan 4 sebaiknya mendapat terapi antiretrovirus seumur hidup. ${ }^{(7)}$

Wanita yang tidak pernah mendapat terapi antiretrovirus dibagi menjadi 2 kategori.

1. Wanita yang memenuhi kriteria inisiasi terapi antiretrovirus pada orang dewasa biasa diberikan HAART tanpa mem-perhatikan trimester berapa, mengguna-kan rejimen yang mengandung zidovudine bila memungkinkan. Nevirapine diberikan bila CD4+ $<250 \mathrm{sel} / \mathrm{mm}^{3}$ oleh karena adanya risiko hepatotoksisitas.

2. Wanita yang tidak memenuhi kriteria indikasi terapi antiretrovirus pada orang dewasa biasa dikonsultasikan keun-tungan terapi inisiasi untuk mencegah transmisi perinatal. Oleh karena efek teratogenik, terapi dapat ditunda sampai trimester kedua. Zidovudine sebaiknya menjadi komponen dari rejimen bila mungkin. Monoterapi zidovudine meru-pakan pilihan untuk ibu yang menginginkan obat yang terbatas. Monoterapi merupakan kontroversial tetapi dapat digunakan untuk ibu dengan HIV RNA < 1000/mL yang tidak mendapat terapi. ${ }^{(8)}$

Kelompok lain dari ibu yang telah mendapat terapi antiretrovirus tetapi sekarang tidak meminum obat. Penggunaan antiretrovirus sebelumnya meningkatkan risiko resistensi obat HIV dan tes resistensi sangat penting. Kelompok terakhir adalah ibu yang datang saat mau kelahiran dan tidak meminum obat sama sekali. Ibu ini diberikan zidovudine intrapartum intravena. Beberapa ahli juga merekomendasikan utuk memberikan 1 dosis nevirapine pada onset kelahiran, dan bila dipilih, pemberian lamivudine untuk 7 hari akan menurunkan perkembangan resistensi nevirapine. ${ }^{(7)}$ Perempuan yang baru terdiagnosis diharapkan memulai terapi baru pada usia gestasi 14 minggu karena risiko pada fetus yang belum jelas. ${ }^{(12,13)}$

\section{Intrapartum}

\section{Pemberian HAART maternal} dengan profilaksis zidovudine intrapartum telah sangat menurunkan risiko transmisi HIV perinatal. Kelahiran dengan ekstraksi forsep atau vakum dihindari. Perdarahan postpartum diterapi dengan oksitosin dan analog prostaglandin karena methergin dan alkaloid ergot lainnya berinteraksi dengan reverse transcriptase dan protease inhibitors pada antiretrovirus yang menyebabkan vasokonstriksi berlebihan. ${ }^{(8)}$ 
Operasi caesar direkomendasikan pada HIV maternal, di mana HIVRNA >1000/mL. Jadwal kelahiran direkomendasikan usia 38 minggu untuk mengurangi kemungkinan ketuban pecah dini. Bila dilakukan operasi caesar, penggunaan profilaksis antimikroba perioperasi direkomendasikan. Transmisi HIV vertikal menurun sekitar setengahnya bila dibandingkan dengan persalinan pervaginam. Dengan terapi antiretrovirus diberikan saat periode prenatal, intrapartum, dan neonatus, ditambah persalinan caesar, transmisi neonatal menurun $87 \%$ dibandingkan dengan cara kelahiran lain dan tanpa terapi antiretrovirus. ${ }^{(8)}$

Untuk operasi caesar elektif (terencana), profilaksis antiretrovirus sdNevirapine+Tenovofir+Emtracitabine (sdNVP+TDF+FTC) harus diberikan 4 jam sebelum operasi dilakukan. Wanita yang menjalani terapi ART tetap melanjutkan rejimennya. Risiko MTCT meningkat oleh adanya ketuban pecah lama, persalinan yang dibantu dengan alat (ekstraksi), prosedur yang invasif, episiotomi, dan prematuritas. ${ }^{(7)}$

Selama proses persalinan, status imunitas sang ibu harus diketahui. Jika status HIV tidak diketahui dan pasien tersebut sedang dalam persalinan kala satu, tes HIV dan konseling harus segera dilakukan. Wanita yang HIV positif dan tidak menerima pengobatan ART seumur hidup harus mendapatkan AZT 3 jam dan sdNVP. Setelah proses persalinan segera berikan single dose TDF+FTC (Tenofovir+Emtracitabine). Wanita yang sedang dalam pengobatan ART seumur hidup tetap melanjutkan rejimen tersebut selama proses persalinan. Wanita tersebut tidak memerlukan tambahan sdNVP atau AZT 3 jam atau TDF dan FTC. ${ }^{(7)}$

Tabel 4. Pemberian Rejimen Zidovudine ${ }^{(8,14)}$

Pediatric AIDS Clinical Trials Group (PACTG) Rejimen Zidovudine

$\begin{array}{ll}\text { Waktu } & \text { Regimen Zidovudine } \\ \text { pemberian } & \end{array}$

Antepartum $100 \mathrm{mg}$ oral 5 kali sehari, diinisiasi saat usia 14-34 minggu dan diteruskan sepanjang kehamilan. ${ }^{a}$

\begin{tabular}{ll}
\hline Intrapartum & $\begin{array}{l}\text { Selama kelahiran, zidovudine intravena selama dosis inisial } 2 \\
\mathrm{mg} / \mathrm{kg} \text { selama } 1 \mathrm{jam} \text {, diikuti infus } 1 \mathrm{mg} / \mathrm{kg} / \mathrm{jam} \text { sampai } \\
\text { kelahiran. }\end{array}$ \\
\hline Neonatal & $\begin{array}{l}\text { Dimulai saat } 8-12 \text { jam setelah lahir dan berikan sirup } 2 \mathrm{mg} / \mathrm{kg} \\
\text { setiap } 6 \text { jam untuk } 6 \text { minggu. }\end{array}$
\end{tabular}

\footnotetext{
${ }^{\mathrm{a}}$ Regimen alternatif $200 \mathrm{mg} 3$ kali sehari atau $300 \mathrm{mg} 2$ kali sehari.

${ }^{\mathrm{b}}$ Untuk operasi caesar elektif, zidovudine intravena dimulai paling tidak 3 jam sebelum operasi. Untuk ketuban pecah dini atau kelahiran dengan intervensi, loading dose dapat diberikan $1 / 2$ jam sebelumnya.

${ }^{\mathrm{c}}$ Dosis intravena untuk bayi yang tidak toleransi asupan oral $1,5 \mathrm{mg} / \mathrm{kg}$ intravena setiap 6 jam.
} 
Postpartum

Dalam perawatan bayi baru lahir dari ibu dengan HIV harus menggunakan prinsip standard precautions untuk melindungi petugas kesehatan dari risiko penularan. Bayi dengan usia gestasi $>32$ bulan dan dalam kondisi stabil, harus segera dimandikan dengan menggunakan chlorhexidine $1 \%$ (hindari pajanan ke mata bayi). Setelah bayi dimandikan lalu dapat diberikan injeksi vitamin $\mathrm{K}$ IM (berat badan <1500 gram diberikan $0,5 \mathrm{mg}$ vitamin $\mathrm{K}$ atau berat badan $>1500$ gram diberikan $1 \mathrm{mg}$ vitamin $\mathrm{K}$ ). Pemberian vaksin BCG (Bacille Calmette Guerin) dan vaksin hidup lainnya tidak diberikan pada bayi dengan status HIV yang belum jelas. ${ }^{(15)}$

Pemberian ASI eksklusif 6 bulan menurunkan risiko transmisi HIV dibandingkan ASI dicampur dengan susu formula. ${ }^{(16,17)}$ Sang ibu harus terus mendapatkan rejimen ART untuk mencegah MTCT. Di USA dan Kanada, di mana susu formula aman dan tersedia, ibu dengan HIV diharapkan untuk tidak memberikan ASI meskipun dia mendapatkan terapi antiretrovirus. ${ }^{(9,18)}$ Pada negara dengan angka infeksi, malnutrisi dan infant mortality rate yang tinggi direkomendasikan oleh WHO untuk memberikan ASI minimal 6 bulan dan dapat diperpanjang hingga tersedia pengganti ASI yang memenuhi kriteria AFASS (acceptable, feasible, affordable, sustainable and safe). Ketika sang ibu hendak menghentikan pemberian ASI, proses penghentiannya sebaiknya dilakukan bertahap dalam 1 bulan. ${ }^{(19)}$

Semua bayi yang telah dikonfirmasi terdapat infeksi HIV harus memulai ART, tanpa mempedulikan tahap klinis atau imunologik. Jika tidak terdapat tes virus, bayi $<12$ bulan dengan diagnosis klinis, infeksi HIV berat berdasarkan dugaan harus memulai ART secepat mungkin. Konfirmasi infeksi HIV harus dilakukan secepatnya. ${ }^{(20)}$

Profilaksis diberikan segera setelah lahir. Bayi tersebut harus mendapat Nevirapin sesegera mungkin (<72 jam) setelah lahir dan dilanjutkan hingga status HIV diketahui (minimal 6 minggu), dapat melalui rapid test maupun tes ELISA. NVP dilanjutkan hingga usia 6 minggu dan diikuti dengan tes PCR pada minggu ke-6. Jika status kesehatan ibu tidak diketahui maka bayi harus mendapatkan Nevirapin dan tes HIV (ELISA atau rapid test) untuk menentukan penanganan selanjutnya. Dosis yang diberikan bila berat badan lahir $\geq 2,5 \mathrm{~kg}$ adalah $15 \mathrm{mg}$ dan bila berat badan lahir $<2.5 \mathrm{~kg}$ adalah $10 \mathrm{mg}$. ${ }^{(21)}$

Jumlah CD4+ pada bayi sehat yang tidak terinfeksi HIV lebih tinggi daripada orang dewasa yang sehat, dan akan menurun sampai nilai orang dewasa pada usia 5-6 tahun. Oleh karena itu, tidak mungkin untuk menetapkan ambang batas tunggal untuk menentukan kapan harus memulai ART. ${ }^{(20)}$ 
Tabel 5. Rekomendasi untuk inisiasi ART pada bayi dan anak ${ }^{(20)}$

\begin{tabular}{|c|c|c|c|}
\hline Age & $\begin{array}{l}\text { Infants and children } \\
<24 \text { months of age } e^{\mathrm{a}, \mathrm{b}}\end{array}$ & $\begin{array}{l}\geq 24 \text { months of age to } 59 \\
\text { months of age }\end{array}$ & $\begin{array}{l}\text { Five years of age or } \\
\text { older }\end{array}$ \\
\hline$\% C D 4+$ & Allc & $\leq 25$ & NA \\
\hline Absolute CD4 & All & $\leq 750$ cells $/ \mathrm{mm}^{3}$ & $\begin{array}{l}\leq 350 \text { cells } / \mathrm{mm}^{3} \\
\text { (As in adults) }\end{array}$ \\
\hline \multicolumn{4}{|c|}{ a All HIV-infected infants should receive ART due to the rapid rate of disease progression. } \\
\hline \multicolumn{4}{|c|}{$\begin{array}{l}\text { Countries with reliable access to CD4 monitoring may choose to apply clinical and immunological criteria for initiation of ART } \\
\text { in children aged } 12-23 \text { months. }\end{array}$} \\
\hline \multicolumn{4}{|c|}{ c In children with absolute lymphopaenia, the $\mathrm{CD} 4$ percentage $(\% \mathrm{CD} 4+)$ may be falsely elevated. } \\
\hline
\end{tabular}

Untuk anak usia $<18$ bulan dengan status infeksi belum pasti dilakukan uji antibodi HIV positif. Jika tegak diagnosis presumptif dimulai pemberian ART. Bila uji antibodi HIV negatif, lakukan evaluasi klinis dan nilai CD4+ setiap 3-6 bulan sekali, atau lebih sering pada usia yang lebih muda. Pemantauan TLC tidak diperlukan. ${ }^{(20)}$

Perlu dilakukan penilaian status nutrisi, pertumbuhan, dan kebutuhan intervensinya. Menilai status imunisasi dan berikan imunisasi yang sesuai. Menilai tanda dan gejala infeksi oportunistik dan lakukan pengobatan infeksi oportunistik sebelum pemberian ART. Lakukan penilaian stadium penyakit HIV menggunakan kriteria klinis WHO. Pastikan anak mendapat kotrimoksazol (profilaksis kotrimoksazol: trimetoprim $5 \mathrm{mg} / \mathrm{kg} / \mathrm{hari}$ dan sulfametoksasol $25 \mathrm{mg} / \mathrm{kg} / \mathrm{hari}$ ). Secara umum diindikasikan mulai 4-6 minggu setelah lahir dan dipertahankan sampai tidak ada risiko transmisi HIV dan infeksi HIV disingkirkan untuk mencegah pneumonia. ${ }^{(6)}$

\section{KESIMPULAN}

Infeksi HIV-1 maternal sebaiknya diidentifikasi sebelum atau selama kehamilan. Informasi status koinfeksi maternal seperti TB, sifilis, toksoplasmosis, hepatitis B atau C, CMV, dan HSV perlu dicari untuk mengetahui kemungkinan neonatus terekspos. Antiretrovirus pada maternal selama kehamilan dan persalinan, dilanjutkan 6 bulan terapi zidovudine pada neonatus, secara signifikan menurunkan risiko transmisi. Operasi caesar elektif juga dapat mencegah transmisi vertikal HIV. Tes virologi memungkinkan diagnosis dini HIV dan inisiasi terapi serta pencegahan infeksi oportunistik. Bahkan bila tes negatif, bayi perlu dimonitor ketat hingga usia 18 bulan untuk mengeksklusi infeksi HIV.

\section{KEPUSTAKAAN}

1. Yogev R, Chadwick EG. Acquired immunodeficiency syndrome (human immunodeficiency virus). Dalam: Kliegman RM, Behrman $\mathrm{RE}$, Jenson HB, Stanton BF, penyunting. Nelson textbook of pediatrics. Edisi ke-18. New York: Elsevier's; 2007. 102232. 
2. UNICEF. Prevent mother-tochild transmission of HIV. 2010. Diunduh dari http://www.childinfo.org/hiv_ai ds_mother_to_child.html.

3. UNAIDS report on the global AIDS epidemic. Global Report. 2010. Diunduh dari http://www.unaids.org/globalrep ort/documents/20101123_Globa 1Report_full_en.pdf.

4. Beckenman KP. Identification, evaluation and care of human immunodeficiency virus exposed neonate. Dalam: Adams CI, Anne AM, et al. Avery's disease of the newborn. Edisi ke-8. Philadelphia: Elsevier Churcill Livingstone; 2008. 47592.

5. Meleski ME, Damato EG. HIV exposure: neonatal consideration. Journal of Obstetric, Gynecologic, and Neonatal Nursing 2003;32:10916.

6. Departemen Kesehatan Republik Indonesia. Pedoman tatalaksana infeksi HIV pada anak dan terapi antiretroviral di Indonesia. Jakarta: Departemen Kesehatan Republik Indonesia; 2008.

7. National Department of Health, South Africa, South African National AIDS Council. Clinical guidelines: PMTCT. South Africa: National Department of Health; 2010.

8. Cunningham FG, Leveno KJ, Bloom SL. et al. Sexually transmitted diseases: human immunodeficiency virus (HIV) infection. Dalam: Williams Obstetrics. Edisi ke-23. USA: The Mc Graw Hill Companies; 2010. 1246-53.

9. US Public Health Service. Public health service task force recommendation for the use of antiretroviral drugs in pregnant HIV-1-infected women for maternal health and interventions to reduce perinatal HIV-1 transmission in the United Stated. MMWR Recomm Rep. 2002;51(RR-18):1-40.

10. Moodley D, Moodley J, Coovadia $\mathrm{H}$, et al. A multicenter randomized controlled trial of nevirapine versus a combination of zidovudine and lamivudine to reduce intrapartum and early postpartum mother-to-child transmission of human immunodeficiency virus type 1 . J Infect Dis. 2003;187:725-35.

11. The Petra Study Team. Efficacy of three short course regimens of zidovudine and lamivudine in preventing early and late transmission of HIV-1 from mother to child in Tanzania, South Africa, and Uganda (Petra study): a randomised, doubleblind, placebo-controlled trial. Lancet 2002;359:1178-86.

12. Katz A. The evolving art of caring for pregnant women with HIV infection. Journal of Obstetric, Gynecologic, and Neonatal Nursing 2003; 32:1028.

13. Montgomery KS. Childbirth education for the HIV-positive 
woman. $J$ Perinat Educ. 2003;12(4):16-26.

14. Krist AH, Faucher AC. Management of newborns exposed to maternal HIV infection. Am Fam Physician 2002;65(10):2049-57.

15. Canterbury District Health Board. Guidelines for the management of HIV-infected women during pregnancy and childbirth. New Zealand; 2009. Diunduh dari: http://www.cdhb.govt.nz/cwh/m aternity/maternity_guidelines/lin ked_content/WCHGLM0033HIV-Infection-DuringPregnancy-and-ChildbirthIss1.pdf.

16. Coovadia HM, Rollins NC, Bland RM, et al. Mother-tochild transmission of HIV-1 infection during exclusive breastfeeding in the first 6 months of life: an intervention cohort study. Lancet 2007;369:1107-16.

17. Iliff PJ, Piwoz EG, Tavengwa $\mathrm{NV}$, et al. Early exclusive breastfeeding reduces the risk of postnatal HIV-1 transmission and increases HIV-free survival. AIDS 2005;19:699-708.
18. King SM. Evaluation and treatment of the human immunodeficiency virus-1 exposed infant. Pediatrics 2004;114(2):497-505.

19. Gray GE, Saloojee H. et al. Breastfeeding, antiretroviral prophylaxis and HIV. NEJM 2008;359:189-91.

20. World Health Organization. WHO antiretroviral therapy for HIV infection in infants and children : towards universal access. Recommendation for public approach 2010 revision. Austria; 2010. Diunduh dari http://whqlibdoc.who.int/publica tions/2010/9789241599801_eng .pdf.

21. World Health Organization. HIV and infant feeding. Guidelines for decision-maker. Jenewa; 2010. Diunduh dari: http://www.who.int/nutrition/pu blications/hivaids/97892415995 35/en/index.html. 